\title{
The Impact of COVID Pandemic Consequences on Public Demand for Competence Formation in Humanitarian Education
}

\author{
Yuri Vsevolodovich Maslov리 Iryna Sergiivna Pypenko², Yuriy Borysovych Melnyk ${ }^{3}$ \\ ${ }^{1}$ PhD, Associate Professor, Belarusian State Economic University, Belarus; maslove@tut.by; \\ https://orcid.org/0000-0002-5715-6546. \\ ${ }^{2} \mathrm{PhD}$, Associate Professor, Simon Kuznets Kharkiv National University of Economics; Scientific Research \\ Institute KRPOCH, Ukraine; iryna.pypenko@hneu.net; https://orcid.org/0000-0001-5083-540X \\ ${ }^{3} \mathrm{PhD}$, Associate Professor, Scientific Research Institute KRPOCH; Kharkiv Regional Public Organization \\ "Culture of Health", Ukraine; y.b.melnyk@gmail.com; https://orcid.org/0000-0002-8527-4638
}

\begin{abstract}
The COVID pandemic has affected all human activity, most of all education. Lockdowns obliterated traditional teaching. Student attitudes towards educational format and content have also changed. The aim of this paper is to evaluate the impact of the pandemic consequences on public demand for competence formation in humanitarian education. Gathered through systemic written surveys (Project Tuning methodology) and interviewing the respondents (173 faculty and 322 students), participants to CIES-2020 and PPPMSF-2021 international conferences, the data were systematized, rated and analyzed using the methods of statistical analysis. Consequently, actual public demand for student competences was formulated. Top five choices by the faculty include: 1) ability to adapt to and act in new situation; 2) commitment to safety; 3 ) ability to search for, process and analyze information; 4) skills in the use of information and communications technologies; 5) ability to evaluate and maintain the quality of work. The student choices differ from faculty prioritizing the abilities: 1) to work autonomously; 2) to design and manage projects; 3 ) to adapt to and act in new situation; 4) to apply knowledge in practical situations; 5) to work in an international context. The results have shown a statistically significant difference between the public demand prior to the pandemic and after the introduction of social distancing measures. Views of faculty and students on the importance of particular competences have remained divergent, and the specific priorities are changing. One noticeable trend is prioritizing the ability to adapt to new situations by both faculty and students.
\end{abstract}

Keywords: Humanitarian Education, Faculty and Students, Competences' Rating, Social Distancing

\section{Introduction}

The COVID pandemic has had an impact on all spheres of human activity. The sphere of higher education is no exception. In many countries of the world, the pandemic has resulted in temporary closures of higher education institutions. According to the estimates, approximately 220 million students have been affected globally due to the disruption caused by the pandemic (Farnell,

This Open Access article is published under a Creative Commons Attribution Non-Commercial 4.0 International License (http://creativecommons.org/licenses/by-nc/4.0/), which permits non-commercial re-use, distribution, and reproduction in any medium, provided the original work is properly cited. For citation use the DOI. For commercial re-use, please contact editor@rupkatha.com. 
Skledar Matijević, \& Šćukanec Schmidt, 2021). This ongoing crisis situation remains an unprecedented challenge for policymakers and educators alike.

Researchers have also noted that the crisis is having a positive effect on education (Magomedov, Khaliev, \& Khubolov, 2020), emphasizing, among other things, the process of massive integration of technology into education. Some researchers have argued that such changes have a "revolutionizing effect" on higher education (Melnyk, Pypenko, \& Maslov, 2020).

However, somewhat less attention is paid to online pedagogies, the human dimension of teaching and learning (Gatti et al., 2020). Yet this dimension may become the most crucial area of long-term change. That is why there is a dire need to become "aware and plan how to react, by understanding that this is a potential catalyst for change of traditional policies and institutions" (Blankenberger \& Williams, 2020). The "ecosystem" of higher education needs to react to achieve a new equilibrium.

Faculty and administrators are not the only stakeholders who need to seek for solutions. Student attitudes towards educational format and content have also changed due to the pandemic. Research has shown that the effects the pandemic have been highly heterogeneous as economic and health shocks vary by socioeconomic status of the students and act as key mediators explaining the effects of the crisis (Aucejo, French, Araya, \& Zafar, 2020; Tsoulou, Babalis, \& Tsoli, 2020).

Referring to "educational shocks", researchers report that the delivery of emergency remote teaching is evaluated positively by students overall. Moreover, students generally display higher levels of satisfaction with and preparedness for emergency remote learning that faculty (Pypenko, Maslov, \& Melnyk, 2020). Simultaneously, a significant proportion of students encountered serious challenges in their learning (Farnell et al., 2021), which is more of a problem in the countries with less reliable ICT infrastructure and internet access. Many students also are of the opinion that their academic performance has changed for the worse since on-site classes were cancelled. More than half of the students report having a larger workload since the transition to online teaching.

One of the central issues in the pandemic-affected educational environment is how to maintain the quality of education and assess the outcomes.

In the European Union, researchers connect medium-term risks for the development of higher education with the problem of assessment procedures. Farnell et al. (2021) point out that it is necessary, primarily, to adapt assessment processes to safeguard quality standards and academic integrity in the context of online learning. It is also advisable to adapt quality assurance regulations for a more flexible approach to address the online and blended delivery of study programs. To minimize the lack of confidence in online learning, educators should also address potential negative consequences on the recognition of qualifications on the labor market.

Gatti et al. (2020) emphasize that the transition to online teaching demands for prompt and purposeful adaptation of assessment and grading procedures. Moreover, students themselves demonstrate varying degrees of ability to adapt to a new learning environment, which shows again that there is no one-size-fits-all pedagogy for online learning (Pokhreli \& Cchetri, 2021). According 
to reports, even for students and teachers in countries with reliable ICT infrastructure and internet access, the rapid transition to online learning has been challenging (Tadesse \& Muluye, 2020).

However, assessment of outcomes in higher education, however hard potential employers press for it, is traditionally very difficult. Blankenberger and Williams (2020) maintain that higher education institutions are supposed to be measuring higher-order knowledge, skills, and reasoning, but these are stronger on internal validity and less strong on external validity. That brings about the ethical issue of institutional accountability and integrity, especially under the pandemic-driven stress.

Tadesse and Muluye (2020) underlines that the assessment and evaluation of students' performance in online learning is difficult for both instructors and students especially when teaching deals with developing praxis-oriented competencies and skills. When dealing with teaching the Humanities, the problem of competences' formation is also challenging because assessment should include the techniques for measuring higher-order knowledge. In conditions of remote teaching/learning though such techniques are not easy to apply.

The concept of competence, one of the buzz words in contemporary educational discourse, has attracted a lot of researchers' attention. The widely accepted definition of key competences suggests that they are learnable and, to some extent, teachable.

Key competences, when mastered, are supposed to contribute to highly-valued individual outcomes (gainful employment, personal health and safety, access to intellectual resources, and political and cultural participation) and societal outcomes (economic productivity, engagement in democratic processes, consolidation of social cohesion, human rights and peace, equity and equality). In sum, key competences are instrumental for meeting complex demands the society places on the individual, which explains the fact that higher education systems put a high premium on their formation.

The competence model should combine intellectual abilities, content-specific knowledge, cognitive skills, domain-specific strategies, motivational tendencies, volitional control systems, personal value orientations, and social behavior systems (Weinert, 2001).

Rychen \& Salganik (2003) postulated the need to face the challenges of the $21^{\text {st }}$ century world by developing the set of competences related to creativity, empathy, dealing with ambiguity, engagement with uncertainty, stewardship, patience and sense-making, adapting in the face of disruptive change, long-term thinking, and anticipation.

A systematic review of studies on $21^{\text {st }}$ century skills (Chalkiadaki, 2018) resulted in a broad range of skill sets and professional attributes, including: creativity, divergent thinking, critical thinking, team working (especially in heterogeneous groups), work autonomy, developed cognitive and interpersonal skills, social and civic competences, responsible national and global citizenship, consciousness of interdependence, acceptance and understanding of diversity, recognition and development of personal attributes, interactive use of tools, communication in mother tongue and foreign languages, mathematical and science competence, digital competence, sense of initiative and entrepreneurship, accountability, leadership, cultural awareness and expression, and physical well-being. 
As is known, the study of competences was one of the key tasks of the Tuning Project initiated by the European universities in 2000. A specialized Tuning SQF project was implemented in 2007, the purpose of which was to develop a sectorial framework of qualifications consistent with the requirements existing in the European Higher Education Area (Melnyk, 2017).

Based on experience of more than 100 universities from 16 countries participating in Bologna process (5183 graduates, 998 academics and 944 employers took part in consultations and questionnaires), 31 generic competences were selected from 3 categories: instrumental, interpersonal and systemic (Melnyk, 2017; Zakharchenko, Luhovyi, Rashkevych, \& Talanova, 2014).

Instrumental competences include cognitive, methodological, technological and linguistic abilities. These include the ability use high-order mental skills (analysis and synthesis), and organize and plan activities; to acquire profession-related basic knowledge; to communicate in one's native and a foreign language (orally and in written form); to use ICTs at elementary level; to find and analyze relevant information; to solve problems and make decisions.

Interpersonal competences include communication, social interaction and cooperation skills such as the ability to think critically (including self-criticism); to work in interdisciplinary teams; to communicate with experts from other fields; to display positive attitude towards cultural differences; to work in intercultural milieu; to meet ethical obligations.

Systemic competences are a combination of understanding, sensitivity and knowledge. These include the ability to make improvements and develop new systems; to put knowledge and skills to practice; to do research; to learn and adapt to new situations; to generate new ideas (creativity); to perform leadership roles; to work autonomously; to display initiative and entrepreneurial spirit; to focus on quality; to achieve success.

It is obvious that, under the circumstances, the approach of faculty toward the formation of competencies needs rethinking, especially in teaching the Humanities. The process should correspond to the "public demand" that is now being affected by the global pandemic.

The aim of this paper is to evaluate the impact of the pandemic consequences on public demand for competence formation in humanitarian education.

In this case, the "public" are the two higher education stakeholders - faculty and students. It makes sense to study the changing preferences that these groups display, as the results of such studies can give valuable insights into the process of educational design in its multiple forms and formats.

\section{Material and Methods}

The authors approach the study of public demand for competence formation in humanitarian education using the taxonomy of competences developed by Project Tuning international experts (Zakharchenko et al., 2014). This methodology has a number of advantages such as multidimensional evaluation of competences selected by faculty and students; determination of priorities in competence formation at university; evaluation of competences on the basis of open data received directly from education stakeholders. This methodology bears dynamic character 
and provides opportunities for relatively simple processing of data using mathematical statistics instruments.

The study was conducted on the basis of written responses (Project Tuning methodology) and interviews with the participants to CIES-2020 (Maslov \& Melnyk, 2020; Melnyk, 2020) and PPPMSF-2021 (Maslov \& Maslova, 2021) international conferences (173 faculty and 322 students).

The respondents were offered a list of 31 generic competences and asked to rank the top five that they consider most important. Faculty were to select those they thought most appropriate as teaching objectives, and students were to select those they thought most crucial for further careers. The data collected through surveys, interviews, and discussions were systematized, rated and analyzed using the methods of statistical analysis.

To obtain ranked scores, we used the algorithm for calculating mean values - weighted arithmetic mean calculated on the basis of the values of changeable subject from 1 to 5 with the account of weightiness. Besides, the values of the subject were represented as a variable distribution series, in which the number of units was not the same. In this case, weighting was carried out in accordance with frequency ratio (competences' weightiness from 1 to 5) indicating the number of repetitions of the same choice. For this reason, when calculating weighted arithmetic mean for each selected competence, all values of weightiness within the range from 1 to 5 were multiplied by the frequency of their repetition, the results summed up and then divided by the total of frequencies, i.e. overall total.

\section{Results}

The results obtained while interviewing faculty and students were systematized and calculated to determine the rankings of specific competences.

Prior to the pandemic, the total number of respondents was 430 (100.0\%). 143 respondents (33.3\%) selected the competences that formed the list of those ranked top five.

During the pandemic, the total number of respondents was 495 (100.0\%) including 173 faculty (34.9\%) and 322 students (65.1\%). 208 respondents (42.0\%) selected the top five competences, among whom 94 were faculty (54.3\%) and 114 were students (35.4\%).

The data obtained from both groups made it possible to develop the list of priority competences relevant for these stakeholders, and to compare the choice prior to and during the pandemic. The results of competence ranking made by faculty are given in Table 1.

Table 1: Type of competence rankings by faculty. 
Number of competences

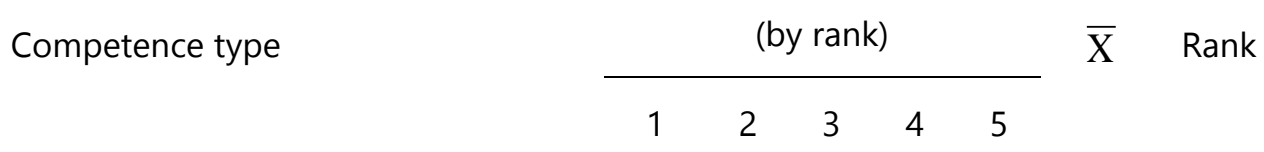

\begin{tabular}{lrrrrrrr}
\hline $\begin{array}{l}\text { Skills in the use of information and communications } \\
\text { technologies }\end{array}$ & 32 & 20 & 8 & 14 & 10 & 13.47 & 4 \\
Ability to search for, process and analyze information & 33 & 19 & 20 & 13 & 8 & 14.87 & 3 \\
Ability to adapt to and act in new situation & 37 & 24 & 21 & 18 & 17 & 20.33 & 1 \\
Commitment to safety & 30 & 20 & 21 & 22 & 13 & 19.07 & 2 \\
Ability to evaluate and maintain the quality of work & 27 & 19 & 7 & 11 & 6 & 10.67 & 5 \\
\hline
\end{tabular}

Note. $\overline{\mathrm{X}}$ - the weighted arithmetic mean.

For example, the weighted arithmetic mean for commitment to safety was calculated as follows: $\quad \frac{5 \times 13+4 \times 22+3 \times 21+2 \times 20+1 \times 30}{5+4+3+2+1}=19.07$. Calculations for other competences selected by respondents were carried out in a similar fashion. The highest value of the weighted arithmetic mean is rated 1 , and the lowest -5 .

Top five choices by the faculty include: ability to adapt to and act in new situation; commitment to safety; ability to search for, process and analyze information; skills in the use of information and communications technologies; ability to evaluate and maintain the quality of work.

The public demand for other types of competences was either very weak or non-existent.

Table 2 shows the comparison between student-made rankings obtained prior to and during the COVID pandemic at national, European and international levels.

Table 2: Rankings of competences made by students prior to and during the COVID pandemic at national, European and international levels.

\begin{tabular}{ccc}
\hline & Competence type & \\
\hline \multicolumn{1}{c}{ Prior to the pandemic } & During the pandemic \\
\hline $\begin{array}{c}\text { European level, Project Tuning } \\
\text { (Zakharchenko, 2014) }\end{array}$ & National level (Melnyk, 2017) & $\begin{array}{c}\text { International level (Maslov \& } \\
\text { Melnyk, 2020) }\end{array}$ \\
\hline 1 Ability for abstract thinking, \\
$\begin{array}{l}\text { analysis and synthesis } \\
\text { Determination and } \\
\text { perseverance in the tasks given } \\
\text { and responsibilities taken }\end{array}$ & Ability to work autonomously \\
\hline
\end{tabular}


7 The Impact of COVID Pandemic Consequences on Public Demand for Competence Formation in Humanitarian Education

2 Capacity to learn and stay up-todate with learning

3 Ability to apply knowledge in practical situations

4 Skills in the use of ICTs

5 Ability to adapt to and act in new situation
Ability to make reasoned decisions

Ability to apply knowledge in practical situations

Ability to work in a team

Ability to adapt to and act in new situation
Ability to design and manage projects

Ability to adapt to and act in new situation

Ability to apply knowledge in practical situations

Ability to work in an international context

The results obtained in this study show that, prior to the pandemic, students selected two competences (at the European and national levels) that were ranked similarly - the ability to apply knowledge in practical situations, and the ability to adapt to and act in new situation. All other choices differ significantly.

During the pandemic, student demand for competence formation seems to have changed, as new competences were ranked highly - the ability to work autonomously, and to design and manage projects. The weight values of competences connected with the ability to adapt to and act in new situation, and to apply knowledge in practical situations have changed. Ranked $5^{\text {th }}$, the ability to work in an international context seems to be the competence that began to figure prominently in public demand during the pandemic.

Table 3 shows the results of the comparative analysis of rankings provided by students and faculty.

Table 3: Comparative analysis of rankings obtained from students and faculty prior to and during the COVID pandemic.

\begin{tabular}{|c|c|c|c|c|c|c|c|c|c|c|c|c|}
\hline \multirow{3}{*}{ Respondents } & \multicolumn{12}{|c|}{ Number of choices of most relevant competences (n) } \\
\hline & \multicolumn{2}{|c|}{ Rank "5" } & \multicolumn{2}{|c|}{ Rank "4" } & \multicolumn{2}{|c|}{ Rank "3" } & \multicolumn{2}{|c|}{ Rank "2" } & \multicolumn{2}{|c|}{ Rank "1" } & \multicolumn{2}{|c|}{ Total } \\
\hline & $\mathrm{n}$ & $\%$ & $\mathrm{n}$ & $\%$ & $\mathrm{n}$ & $\%$ & $\mathrm{n}$ & $\%$ & $\mathrm{n}$ & $\%$ & $\mathrm{n}$ & $\%$ \\
\hline $\begin{array}{l}\text { Students } \\
\text { prior to } \\
\text { pandemic }\end{array}$ & 23 & 16.4 & 22 & 15.4 & 24 & 17.1 & 30 & 21.0 & 43 & 30.2 & 143 & 100.0 \\
\hline $\begin{array}{l}\text { Students } \\
\text { during } \\
\text { pandemic }\end{array}$ & 19 & 17.0 & 15 & 13.3 & 22 & 19.3 & 20 & 17.9 & 37 & 32.5 & 114 & 100.0 \\
\hline $\begin{array}{l}\text { Faculty } \\
\text { during } \\
\text { pandemic }\end{array}$ & 11 & 11.5 & 16 & 16.6 & 15 & 16.4 & 20 & 21.7 & 32 & 33.8 & 94 & 100.0 \\
\hline
\end{tabular}


The comparative analysis allows following the dynamics of change in the select competences' rankings obtained from students and faculty prior to and during the pandemic.

The results have shown a statistically significant difference between the public demand prior to the pandemic and after the introduction of social distancing measures.

Table 4 shows the rankings obtained from faculty and students during the COVID pandemic.

Table 4: Comparison of competence rankings obtained from faculty and students during the COVID pandemic.

\begin{tabular}{cll}
\hline Rank & \multicolumn{1}{c}{ Faculty } & \multicolumn{1}{c}{ Students } \\
\hline 1 & $\begin{array}{l}\text { Ability to adapt to and act in new } \\
\text { situation }\end{array}$ & Ability to work autonomously \\
2 & Commitment to safety & Ability to design and manage projects \\
3 & $\begin{array}{l}\text { Ability to search for, process and } \\
\text { analyze information }\end{array}$ & Ability to adapt to and act in new situation \\
4 & Skills in the use of ICTs & Ability to apply knowledge in practical situations \\
5 & $\begin{array}{l}\text { Ability to evaluate and maintain the } \\
\text { quality of work }\end{array}$ & Ability to work in an international context
\end{tabular}

The comparison of the responses obtained from two groups of stakeholders has made it possible to identify the differences in their views on the relative importance of competences in teaching and learning the Humanities.

\section{Discussion}

A diversity that exists in the definitions of competences may make their delivery difficult. Moreover, competences should not be confused with skills and tools or techniques, which can create confusion when developing educational programs. Typically, skills take more time to develop than techniques do to master, and failing to distinguish between them may create additional difficulties. Indeed, universities are increasingly moving toward competency frameworks all over the world, but still there is little consistency in the approaches or definitions used, and often the competence frameworks appear to emerge from the programs themselves rather than employer needs, or well-established and measurable frameworks.

One other problem is the diversity of contexts. Joynes, Rossignoli, \& Fenyiwa AmonooKuofi (2019) points out that there is evidence of a potential disconnect between particular definitions of $21^{\text {st }}$ century skills and their application. The range of attributes in many frameworks indicate the prioritization of skill sets for operating within a highly connected, highly resourced, globally diverse knowledge-based economy. This contrasts significantly with discussions of future need in many development contexts which often seek to highlight the so-called 'life skills'. 
The global pandemic is clearly a crisis that couldn't fail to bring about changes in what is seen as competences of priority by both faculty and students.

Students are on the receiving end of the educational process. Prior to the global pandemic, the competences they viewed as important seem to have been similar both in the European and national context (Table 1). Interestingly, the ability to apply knowledge in practical situations and the ability to adapt to and act in new situations were ranked $3^{\text {rd }}$ and $5^{\text {th }}$ both by a representative group of respondents across Europe and a focus group monitored nationally. More recently, the ability to adapt to and act in new situations was ranked higher by the student participants of international conferences, which may be viewed as a direct impact of the global pandemic that has transformed educational contexts quite dramatically.

Moreover, the results indicate that the ability to apply ICTs has ceased to be one of the priorities for contemporary students, as the measure of digitalization of higher education is growing fast. The students of today, members of Generation Z, seem to take the skills related to ICTs for granted.

The impact of the global pandemic seems to be more "visible" in the rankings made by faculty (Table 2), the leading priorities being the ability to adapt to and act in new situations and, unsurprisingly, commitment to safety. Emergency remote teaching formats may have prompted rankings $3-5$, as faculty members have put a high premium on the skills related to handling information and applying ICTs.

However, such choices may also be viewed from a different perspective. In fact, faculty leaned towards instrumental competences, the lack of which can be a serious impediment to teaching. Learners of today, on the other hand, perceive systemic competences as more valuable assets, which may reflect a more "global" approach to competency-based formats of higher education that contemporary students display.

The pandemic turned out to be a crucial factor impacting faculty and student priorities in evaluating competences all over the world (Georgieva \& Borisova, 2020; Kapasia et al., 2020; Melnyk, Pypenko, \& Maslov, 2020; Sahoo, Muduli, Luhach, \& Poonia, 2021; Soni, 2020). It must have been the result of the effect of the pandemic on every aspect of the educational process economic, social, psychological, etc. The aspect of health protection should not be underestimated, as the COVID pandemic impacted all the stakeholders' mental health. Grave consequences of the pandemic have manifested themselves in student behavior, which included disillusionment, stress, and depression (Chaturvedi, Vishwakarma, \& Singh, 2021; Sahu, 2020; Zhai \& Du, 2020). Such psychological phenomena may have triggered changes in their demand for competence formation in humanitarian education.

Thus, the importance of the competence that was generally overlooked by researchers (commitment to safety) has grown considerably. This leads to the necessity for pedagogical, psychological, and medical support of the stakeholders in extreme conditions of the pandemic (Liu, Pinder-Amaker, Hahm, \& Chen, 2020; Melnyk \& Stadnik, 2020). Under the circumstances, interdisciplinary collaboration of researchers should become standard practice resulting in multipurpose support of the educational process, which can minimize the pandemic's negative impact for the benefit of all educational stakeholders. 


\section{Conclusions}

The public demand for the delivery of particular competences can be described as a fairly complex phenomenon, as it includes all the education stakeholders. Faculty and students are the actors directly responsible for the formation of a specific demand. Their views on and attitudes to particular competences shape it to a large extent.

Having studied the problem for almost a decade, the authors found that public demand differs at the national (Ukraine), pan-European (The European Union), and international level. The results of the study testify to the fact that views of faculty and students on the importance of particular competences remain divergent. Yet the COVID pandemic may have strongly affected public demand, which manifests itself in prioritizing the ability to adapt to new situations by both faculty and students.

The results of the present study of the impact of COVID pandemic on public demand for competence formation in humanitarian education suggest the beginning of global-scale changes in higher education systems.

\section{References}

Aucejo, E. M., French, J., Araya, M. P. U., \& Zafar, B. (2020). The impact of COVID-19 on student experiences and expectations: Evidence from a survey. Journal of Public Economics, 191, 104271. https://doi.org/10.1016/j.jpubeco.2020.104271

Blankenberger, B., \& Williams, A. M. (2020). COVID and the impact on higher education: The essential role of integrity and accountability. Administrative Theory \& Praxis, 42(3), 404-423. https://doi.org/10.1080/10841806.2020.1771907

Chalkiadaki, A. (2018). A systematic literature review of $21^{\text {st }}$ century skills and competencies in primary education. International Journal of Instruction, 11(3), 1-16. https://doi.org/10.12973/iji.2018.1131a

Farnell, T., Skledar Matijević, A., \& Šćukanec Schmidt, N. (2021). The impact of COVID-19 on higher education: a review of emerging evidence (NESET report). Luxembourg: Publications Office of the European Union. https://doi.org/10.2766/069216

Gatti, T., Helm, F., Huskobla, G., Maciejowska, D., McGeever, B., \& Pincemin, J.-M. (2020). Practices at Coimbra Group universities in response to the COVID-19: A collective reflection on the present and future of higher education in Europe. Retrieved from https://www.coimbragroup.eu/wpcontent/uploads/Final-Report-Practices-at-CG-Universities-in-response-to-theCOVID19.pdf

Chaturvedi, K., Vishwakarma, D. K., \& Singh, N. (2021). COVID-19 and its impact on education, social life and mental health of students: A survey. Children and Youth Services Review, 121, 105866. https://doi.org/10.1016/j.childyouth.2020.105866

Georgieva, L. M., \& Borisova, B. V. (2020). An invisible virus has made visible many underestimated problems in medical education and research. International Journal of Science Annals, 3(2), 34-35. https://doi.org/10.26697/ijsa.2020.2.5 
Joynes, C., Rossignoli, S., \& Fenyiwa Amonoo-Kuofi, E. (2019). 21st century skills: Evidence of issues in definition, demand and delivery for development contexts (K4D Helpdesk Report). Brighton, UK: Institute of Development Studies. Retrieved from https://assets.publishing.service.gov.uk/media/5d71187ce5274a097c07b985/21st_century.pdf

Kapasia, N., Paul, P., Roy, A., Saha, J., Zaveri, A., Mallick, R., ... Chouhan, P. (2020). Impact of lockdown on learning status of undergraduate and postgraduate students during COVID-19 pandemic in West Bengal, India. Children and Youth Services Review, 116, 105194. https://doi.org/10.1016/J.CHILDYOUTH.2020.105194

Liu, C. H., Pinder-Amaker, S., Hahm, H., \& Chen, J. A. (2020). Priorities for addressing the impact of the COVID-19 pandemic on college student mental health. Journal of American College Health. https://doi.org/10.1080/07448481.2020.1803882

Magomedov, I. A., Khaliev, M. S-U., \& Khubolov, S. M. (2020). The negative and positive impact of the pandemic on education. Journal of Physics: Conference Series, 1691, 012134. https://doi.org/10.1088/1742-6596/1691/1/012134

Maslov, Y., \& Maslova, M. (2021, June 10-13). What is a student textbook like that can effectively build professional competence? [Virtual presentation]. Psychological and Pedagogical Problems of Modern Specialist Formation, Riga, Latvia - Kharkiv, Ukraine. https://doi.org/10.26697/PPPMSF-21

Maslov, Y., \& Melnyk, Yu. (2020, November 10-11). Competence-based approach in contemporary higher education [Panel discussion]. Current Issues of Education and Science, Riga, Latvia - Kharkiv, Ukraine. https://doi.org/10.26697/CIES-20

Melnyk, Yu. (2020, November 10-11). Study of social demand for the formation of competences in higher education [Webinar]. Current Issues of Education and Science, Riga, Latvia - Kharkiv, Ukraine. https://doi.org/10.26697/CIES-20

Melnyk, Yu. (2017) Study of trends of students' demand for the formation of competences by higher educational institutions. Science and Education, 5, 128-134. https://doi.org/10.24195/2414-46652017-5-22

Melnyk, Yu. B., Pypenko, I. S., \& Maslov, Y. V. (2020). COVID-19 pandemic as a factor revolutionizing the industry of higher education. Rupkatha Journal on Interdisciplinary Studies in Humanities, 12(5). https://doi.org/10.21659/rupkatha.v12n5.rioc1s19n2

Melnyk, Yu. B., \& Stadnik, A. V. (2020). Medical and psychological support to specialists under conditions of pandemic COVID-19. Minerva Psichiatrica, 61(3), 109-112. https://doi.org/10.23736/s03911772.20.02083-X

Pokhrel1, S., \& Chhetri, R. (2021) A literature review on impact of COVID-19 pandemic on teaching and learning. Higher Education for the Future, 8(1), 133-141. https://doi.org/10.1177/2347631120983481

Pypenko, I. S., Maslov, Yu. V., \& Melnyk, Yu. B. (2020). The impact of social distancing measures on higher education stakeholders. International Journal of Science Annals, 3(2), 9-14. https://doi.org/10.26697/ijsa.2020.2.2

Rychen, D. S., \& Salganik, L. H. (Eds.). (2003). Key competencies for a successful life and a well-functioning society. Göttingen, Germany: Hogrefe \& Huber. 
Tadesse, S., \& Muluye, W. (2020). The impact of COVID-19 pandemic on education system in developing countries: A review. Open Journal of Social Sciences, 8, 159-170. https://doi.org/10.4236/jss.2020.810011

Tsolou, O., Babalis, T., \& Tsoli, K. (2021). The impact of COVID-19 pandemic on education: Social exclusion and dropping out of school. Creative Education, 12, 529-544. https://doi.org/10.4236/ce.2021.123036

Sahoo, K. K., Muduli, K. K., Luhach, A. Kr., \& Poonia, R. C. (2021). Pandemic COVID-19: An empirical analysis of impact on Indian higher education system. Journal of Statistics and Management Systems, 24(2), 341-355. https://doi.org/10.1080/09720510.2021.1875571

Sahu, P. (2020). Closure of universities due to coronavirus disease 2019 (COVID-19): Impact on education and mental health of students and academic staff. Cureus, 12(4), e7541. https://doi.org/10.7759/cureus.7541

Soni, V. D. (2020). Global impact of E-learning during COVID 19. http://dx.doi.org/10.2139/ssrn.3630073

Weinert, F. E. (2001). Concept of competence: A conceptual clarification. In D. S. Rychen \& L. H. Salganik (Eds.), Defining and selecting key competencies (pp. 45-65). Hogrefe \& Huber Publishers.

Zakharchenko, V. M., Luhovyi, V. I., Rashkevych, Yu. M., \& Talanova, Zh. V. (2014). Rozroblennia osvitnikh prohram [Development of educational programs]. Kyiv: DP NVTs "Priorytety" [in Ukrainian]

Zhai, Yu., \& Du, X. (2020). Addressing collegiate mental health amid COVID-19 pandemic. Psychiatry Research, 288, 113003. https://doi.org/10.1016/j.psychres.2020.113003 